\title{
Medium-sized cities in decline in France: between urban shrinkage and city centre devitalisation
}

\author{
Julie Chouraqui \\ Received: 15 April 2020 - Accepted: 8 December 2020 - Published online: 29 January 2021
}

\begin{abstract}
Since the end of the 2000s, the question of the decline of French medium-sized towns has become central within the scientific and public debate. More specifically, two processes are underlined: the devitalisation of city centres on the one hand, and urban shrinkage on the other hand. The devitalisation of city centres has been studied in several institutional reports. It is characterised by high rates of vacant housing and high street shops vacancies, a fall in visits to the city centre, an impoverishment of residents and population losses. In geography, urban studies and planning, the dynamics of urban shrinkage have been discussed since the 1990s. They comprise a multidimensional urban crisis, triggered and characterised by job and population losses. This paper attempts to explore the relationships between these processes by underlining their similarities and differences with data analysis and multivariate clustering methods. By comparing mediumsized cities with small and large cities, the specificities of urban decline in medium-sized cities are explored. It appears that cities are not homogeneously affected by urban decline. More particularly, a large number of weakened medium-sized cities display a distinctive feature: markers of decline are concentrated in their urban core.
\end{abstract}

Keywords: Medium-sized cities = urban decline shrinkage - city-centre devitalisation - multivariate analysis

\footnotetext{
$\triangle$ Julie Chouraqui, Université Paris 1 Panthéon-Sorbonne, 191 rue Saint-Jacques, 75005 Paris, France julie.chouraqui@hotmail.fr

(c) (1) (2) (c) 2021 Chouraqui; licensee oekom verlag. This Open Access article is published under the Creative Commons Attribution-ShareAlike 4.0 International Licence.
}

\section{Französische Mittelstädte im Niedergang: zwischen Stadtschrumpfung und Zentrumsverödung}

\section{Zusammenfassung}

Die Frage des Niedergangs von Mittelstädten in Frankreich rückt seit Ende der 2000er-Jahre immer stärker ins Zentrum des wissenschaftlichen und öffentlichen Diskurses. Zwei Entwicklungen stehen dabei besonders im Vordergrund: die Verödung der Stadtzentren und die Schrumpfung der Städte. Über die Zentrumsverödung wurde bereits im Rahmen verschiedener institutioneller Studien berichtet. Sie manifestiert sich in hohen Leerstandsraten bei Wohnimmobilien und Geschäften in Haupteinkaufsstraßen, rückläufigen Zahlen bei Innenstadtbesuchen, Wohlstandsverlusten der Bevölkerung und Bevölkerungsrückgang. Auf die Dynamik der Stadtschrumpfung wird aus den Disziplinen Geographie, Stadtforschung und Städtebau bereits seit den 1990er-Jahren hingewiesen. Sie gleicht einer urbanen Krise mit vielen Dimensionen, deren Ursprünge und Symptome in Verlusten an Arbeitsplätzen und Einwohnern liegen. In diesem Beitrag wird versucht, die Zusammenhänge zwischen diesen Prozessen zu ergründen, indem ihre Ähnlichkeiten und Unterschiede mithilfe von Datenanalysen und multivariaten Cluster-Methoden hervorgehoben werden. Ein weiteres Ziel ist das Untersuchen der spezifischen Ausprägungen des Niedergangs in Mittelstädten im Vergleich zu kleinen und großen Städten. Die Auswirkungen des Städtesterbens scheinen sich nicht allerorts auf die gleiche Weise zu äußern. Als charakteristische Besonderheit zahlreicher angeschlagener Mittelstädte konzentrieren sich die Verfallsmerkmale nämlich auf deren Stadtkern.

Schlüsselwörter: Mittelstädte - städtischer Niedergang Schrumpfung - Verödung von Stadtzentren - multivariate Analyse 


\section{Introduction}

In Europe, small and medium-sized cities have been studied in several countries as a specific level of the urban hierarchy (i.e. France, Spain and Great Britain (Santamaria 2000) or Germany (Adam 2006)). In 2006, the research programme TOWN ${ }^{1}$, launched by the European Spatial Planning Observation Network (ESPON), led to joint reflection about small and medium-sized towns and cities in EU member states. This programme, which lasted until 2014, allowed the identification of such settlements in the 27 member states. According to the results, $24 \%$ of the population of the European Union lives in a small or medium-sized town (ESPON 2012: 8). This attention to small and medium-sized towns in the European Union was, at that time, strongly linked to the objective of social and territorial cohesion, asserted in the European Spatial Development Perspective of 1999 (European Commission 1999).

Indeed, while a convergence of national GDPs has been observed in Europe since the 1990s, socio-economic disparities are observable at finer scales, specifically between regions, cities, and within these spaces (Kühn 2015; Lang 2015). At the regional scale, contrasts are observed between "dynamic, growing metropolitan areas and rural or industrial regions experiencing processes of shrinkage and decline", where small and medium-sized cities are facing more and more difficulties (Kühn 2015: 367). The notions of 'peripheralisation' and 'polarisation' (or 'centralisation') have been used by several German researchers to highlight the reinforcement of regional inequalities in Europe. Peripheralisation and polarisation processes are closely related (Lang 2012; Lang 2015), as "the logic and dynamic of spatial centralisation determine the peripheralisation of other spaces by attracting population, economic productivity and infrastructural functions to the disadvantage of other regions" (Lang 2012: 1750). The movements of polarisation therefore induce a concentration of populations, wealth and activities in a few places, mainly metropolises and their regions, to the detriment of other places. These movements are known to affect some small and mediumsized cities, especially those located in regions isolated from global or metropolitan dynamics. They are driven by social, economic, political and demographic mechanisms, but also by discourses and power interactions that participate in hierarchising territories (Lang 2012; Kühn 2015; Lang/Henn/ Ehrlich et al. 2015; Roth 2016).

The literature about shrinking cities also provides analy-

\footnotetext{
1 https://www.espon.eu/programme/projects/espon-2013/ applied-research/town-\%E2\%80\%93-small-and-medium-sizedtowns (01.11.2020).
}

sis regarding small and medium-sized cities. Urban shrinkage can be defined as a phenomenon of crisis, triggered and characterised by job and population losses (MartinezFernandez/Audirac/Fol et al. 2012: 214). This crisis is in particular characterised by a pauperisation of the population and a degradation of the built environment. Urban shrinkage, often explained by global economic, migratory or political changes, has been observed and studied across Europe, North America and Japan (Oswalt/Rieniets 2006; Martinez-Fernandez/Weyman/Fol et al. 2016). The structural economic dimension of urban shrinkage is emphasised by scholars, as many shrinking cities are former industrial areas facing deindustrialisation (Martinez-Fernandez/ Audirac/Fol et al. 2012; Miot 2012; Wolff/Fol/Roth et al. 2013). In some regions of the world, shrinkage particularly affects small and medium-sized cities. In Europe, Wolff and Wiechmann (2018: 130) showed that the relationship between smaller cities and shrinkage is irregular and varies with region. In southern and western Europe, they observed that shrinkage strongly hits smaller cities, where population decline processes seem to be more recent (beginning in the 2000s and 2005).

In France, several studies about urban shrinkage have indeed shown that this phenomenon tends to primarily affect the lower levels of the urban hierarchy (Fol/CunninghamSabot 2010; Wolff/Fol/Roth et al. 2013; Cauchi-Duval/ Cornuau/Rudolph 2017). Since the end of the 2000s, the decline of medium-sized cities has also become central in the public debate in France. More specifically, the devitalisation of city centres has been the subject of several institutional reports, and has entered political and mediatic discourses. This phenomenon is characterised by high rates of vacant housing and retail vacancies, a fall in visits to the centre, an impoverishment of residents and population losses (CGEDD/IGF 2016; Lestoux 2017; Pointereau/ Bourquin 2017). Such a phenomenon is not specific to France. Indeed, the results of an international literature review conducted in 2018 show that declines of the centres of smaller cities have been observed and studied in Canada, the United States, Great Britain and Spain (Buhnik 2018). The "Maria Portas review on high streets and city centres" illustrates this preoccupation in Great Britain. Ordered by the prime minister in 2011, this report starts by attesting the commercial decline of some British city centres and their high rates of vacancy, before providing some recommendations to revitalise them (Portas 2011). This report led to the launch of a pilot programme to revitalise British high streets in 2012 and to some tax relief measures for city centres (Boutet/Chouraqui/Mauvoisin 2019). In the United States, a report of the Brookings Institution published in 2017 also underlines the decline of smaller cities' central retail functions (Katz/Frey 2017). In the Netherlands, the 
work of Hospers (2017) sheds light on the shop vacancy phenomenon, particularly in small and medium-sized cities. These few examples show that since the turn of 2010, the phenomenon of the devitalisation of city centres seems to have become more and more pronounced in smaller cities across countries.

One of the goals of this paper is to explore urban decline in medium-sized cities in France, and to question the relationships between urban shrinkage and city centre devitalisation. The focus of this paper is specifically on mediumsized cities, because they are central to this debate in France. In this country, medium-sized cities have been targeted by various public policies since the 1970s, and they have progressively been recognised as a category in their own right, studied by researchers since then and considered as distinct from small cities. But by focusing on medium-sized cities, the goal is also to investigate this category and its centrality in the public debate about urban decline. Are all mediumsized cities affected by decline? Are they affected by specific dynamics of decline, in comparison with small or large cities?

Using data analysis and multivariate clustering methods, this paper aims to provide some answers to these questions, and explores the heterogeneity of medium-sized cities in France. Section 2 introduces the notion of medium-sized cities and presents work on the dynamics of decline of these settlements. The methodology used in the study is then presented (Section 3). Subsequently, the results of the analyses, which focus on the demographic trajectories and the socioeconomic composition of French urban areas are presented (Section 4). I then discuss the specificity of medium-sized cities in their dynamics of decline within the French urban system (Section 5), and draw a distinction between urban shrinkage and city centre devitalisation. Section 6 concludes this paper.

\section{Theoretical framework: small and medium-sized cities in France}

\subsection{The French approach to medium-sized cities: an object of discourses and policies since the 1970s}

In France, the notion of ville moyenne (medium-sized city) has been elaborated since the 1970s. It was first created as a reference in territorial policies introduced by the central state that aimed to achieve polycentric spatial organisation in France (Vadelorge 2013: 33). After being used in policy programmes, this term emerged in research and progressively constituted a category of its own. This type of city can be defined according to three main criteria: their posi- tion in the urban hierarchy, their centrality functions, and their specific history and link with public policies. Indeed, medium-sized cities are defined, in France but also in many other countries, as being in an in-between position: they are neither metropolises nor small towns. This implies that they provide a variety of facilities or services, which gives them an influence on their surroundings (Santamaria 2012; Duroudier 2014; Tallec 2014; Demazière 2017). Therefore, medium-sized cities are often described as centres for the surrounding rural areas. Medium-sized cities in France can also be defined in relation to a specific historical and political context, which differentiates them from small cities or towns. Indeed, the urbanisation of medium-sized cities is strongly linked to the rural exodus and Fordist industrialisation (Santamaria 2012; Tallec 2014). During the 1950s and the 1960s, these cities attracted the workforce from the surrounding rural areas, as job opportunities in the newly established factories increased. This development was amplified by public policies, which participated in building discourses about these cities. The political ambition, which remained powerful for decades, was to develop these cities to create urban centres in rural areas, with the mission of providing public services and promoting territorial equilibrium and equity throughout France (Vadelorge 2013).

\subsection{Since the 2000s: several views on the decline of medium-sized cities in France}

From the 2000s onwards, medium-sized cities re-entered French public discourses and policies through the angle of the devitalisation of city centres. Indeed, the centres and high streets of these cities started to be increasingly depicted in the media as spaces in crisis, presented as 'deserted' or 'devitalised'. In 2017, the book "Comment la France a tué ses villes?" (How did France kill its cities?), written by journalist Olivier Razemon, reflects the mediatic coverage of this phenomenon. The author describes the "wounds of medium-sized cities": the weakness of the city centre retail functions, with vacancies and a lack of diversity, the increase of housing vacancy rates and the pauperisation of the city centres are also cited (Razemon 2017: 6177). This multidimensional crisis therefore affects the retail functions of city centres, but also the urban built environment and the population. It has been explained by the dynamics of the sprawl of housing and shops towards urban peripheries, and shifts in the consumption and transport habits of households. In particular, changes within the retail sector, such as the development of malls and hypermarkets, and the democratisation of cars have been pointed out as key to understanding these shifts (Bouvier/Madry 2017; Pointereau/Bourquin 2017; Razemon 2017).

City centre devitalisation also prevails in the discourses 
of public and institutional actors about medium-sized cities. At the national scale, the agenda setting of a 'crisis of medium-sized cities' has continued since 2008, with a focus on the devitalisation of city centres (Dormois/Fol 2017; Pointereau/Bourquin 2017). Since 2016, several reports about the devitalisation of medium-sized cities have been published (CGEDD/IGF 2016; Lestoux 2017; Pointereau/Bourquin 2017) and in 2017, the national programme "Action Coeur de Ville" (City Heart Action) was launched. It specifically targets the revitalisation of medium-sized city centres. In the subsequent five years, 230 cities were to benefit from funding and support for urban renewal projects in their city centres.

In the late 2000s, medium-sized cities also entered the scientific debate in France, but from a different perspective. Studies about urban shrinkage indeed drew attention to medium-sized and small cities, as these types of cities seemed to be more prevalent amongst shrinking cities than larger ones. According to the most recent analyses about demographic decline (Cauchi-Duval/Cornuau/Rudolph 2017: 3 ), small cities are the most affected, as they represent more than two thirds of shrinking cities in France and less than half of the growing or stable cities. Medium-sized cities are less concerned, but still represent $20 \%$ of shrinking cities. As for large cities, they represent about $10 \%$ of shrinking cities, and more than a third of stable or growing cities. In France, shrinking cities are concentrated in the north, northeast and the centre of the country, which are former industrial or remote rural areas. The development of a global production system has been analysed as a key to understanding urban shrinkage in France. Indeed, deindustrialisation induced a deep economic crisis in these territories, and their disconnection from global networks made their economic transformation particularly difficult (CunninghamSabot/Fol 2009; Miot 2012; Wolff/Fol/Roth et al. 2013; Cauchi-Duval/Cornuau/Rudolph 2017). Suburbanisation intensifies processes of urban shrinkage, as it contributes to the weakening of the city by causing demographic losses and a departure of wealthier households (Miot 2012; Fol/ Miot 2014).

The literature about public services closures and state retrenchment has also highlighted the vulnerability of small and medium-sized cities in France with the multiplication of public management reforms since 2007 (Taulelle 2012; Barczak/Hilal 2017; Taulelle 2017; Baudet-Michel/ Conti/Chouraqui et al. 2019). Public management reforms have been conducted in several countries of Europe, North America and Australasia since the 1960s (Pollitt/ Bouckaert 2011). The content of these reforms varies amongst countries but, because they appeared in a specific economic context where state spending was considered inflated, several similarities appear. The New Public Man- agement doctrine has, in particular, widely influenced the content of reforms. This "doctrinal puzzle" (Bezes 2009: 3 ) or the theory's central principle is that the public sector can be improved by imitating the private sector (Bezes 2009; Pollitt/Bouckaert 2011). In France, new spatial distributions of public services were implemented with the "Révision Générale des Politiques Publiques", a programme review inspired by New Public Management principles that was conducted between 2007 and 2012. This programme review's main objective is to optimise public expenditure by reducing state spending when it is too costly and least economically viable. This resulted in public services closures, specifically where their maintenance was most expensive because of lower levels of activity. Rural areas were hit, but so were cities. Amongst cities affected by these reforms, an over-representation of small and, to a lesser extent, mediumsized cities has been demonstrated (Baudet-Michel/Conti/ Chouraqui et al. 2019). To sum up, some public policies seem to favour a process of concentration of public services in more densely populated areas. Metropolises and large cities are, indeed, less affected by public service closures in France. In an economic context that already favours the agglomeration of people, activities and wealth in large cities, such trends may increase territorial inequalities and reinforce the difficulties faced by some small amd mediumsized cities or rural regions.

At the crossroads of these fields of research, several studies focusing on the shrinkage, decline or devitalisation of medium-sized cities emerged after 2010 (Baudet-Michel/ Berroir/Fol et al. 2017; Guéraut 2018; Berroir/Fol/Quéva et al. 2019). They explored the different forms and dimensions of the decline of medium-sized cities, and presented these difficulties as resulting from global economic changes, public services reorganisations and suburbanisation. This paper also follows this line by investigating the different forms of decline in medium-sized cities and their specificity in comparison with large or small cities. More precisely, I concentrate on devitalisation and urban shrinkage processes, which have mostly been studied separately to define the decline of certain medium-sized cities in France. Therefore, their links, interactions and relationship to one another remain unclear. Is it possible to distinguish them from one another? What are their similarities and differences? Do they sometimes overlap?

\section{Data and method: a multi-level cluster analysis of French medium- sized cities}

The main method used to shed light on these issues is data analysis. The data originates from the French census, which 


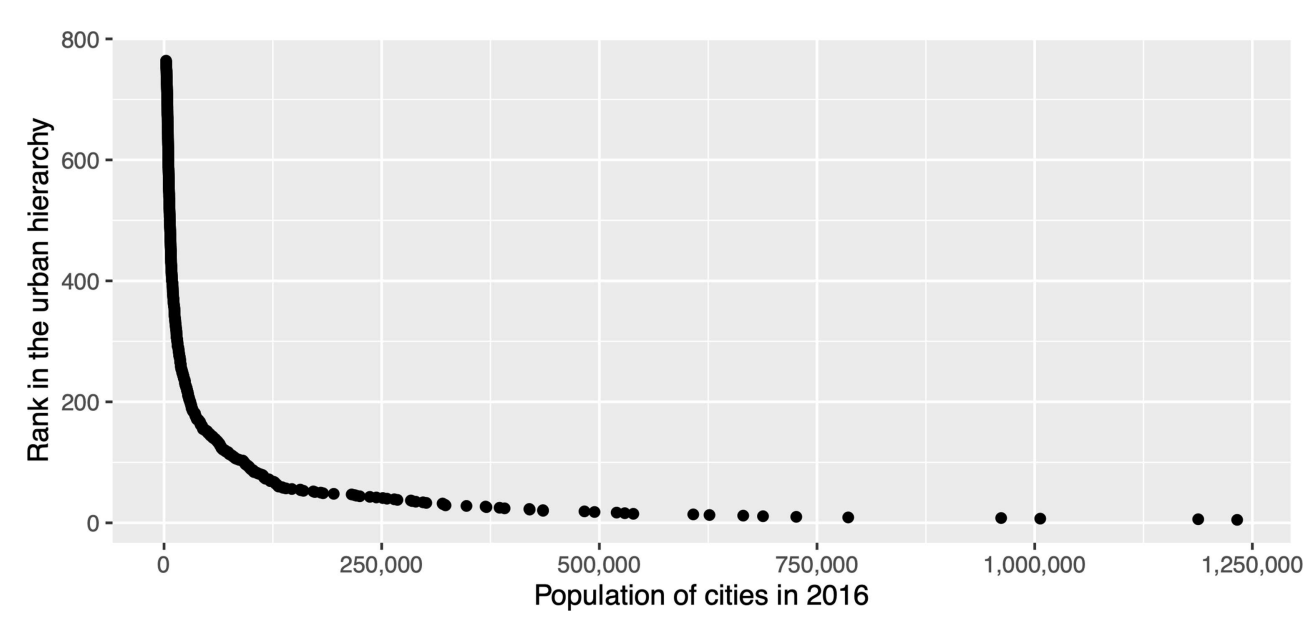

Figure 1 Rank-size diagram of the French urban areas in 2016 Source: Census of the French national institute of statistics (Insee)

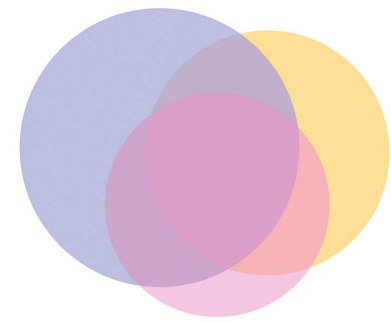

Urban areas with an intermediate position in the urban hierarchy $(n=118)$

Urban areas with a high facility and infrastructure diversity rate $(n=161)$

Urban areas targeted by a national policy programme for medium-sized cities ( $n=190)$ Overlapping zones (at least two criteria): selected urban areas ( $n=166$ )

Figure 2 Diagram of the multi-criteria definition of medium-sized cities

was chosen because of its easy accessibility and the compatibility between variables. I chose the urban area level to conduct my analyses, a functional delimitation of cities created by the French national institute of statistics and economic studies (Insee). ${ }^{2}$

This analysis was conducted in three steps. First, medium-sized cities were defined according to several criteria and French cities were divided in three categories (large cities, medium-sized cities and small cities). Second, two classifications of French cities were conducted to define their socio-economic situation in 2016 and their demographic evolution from 1975 to 2016 . These cluster

\footnotetext{
2 An urban area is a group of contiguous municipalities, encompassing an urban core providing at least 1,500 jobs (the urban unit), surrounded by peripheries, among which at least $40 \%$ of the employed resident population works in the urban core (https: / /www. insee.fr/fr/metadonnees/definition/c2070; 23.11.2020).
}

analyses are used to compare the demographic evolution and socio-economic composition of medium, small and large cities. They allow testing of the hypothesis that there are dynamics of decline specific to medium-sized cities. Lastly, the results of these two classifications were combined for medium-sized cities in order to obtain a synthetic typology of these cities that allows the identification of different forms of decline, in particular urban shrinkage and city centre devitalisation.

\subsection{Definition and selection of medium-sized cities amongst French urban areas}

Firstly, medium-sized cities were selected from all French cities, following the three criteria mentioned above: their in-between position in the urban hierarchy, the influence of the city on its surroundings, and historical specificity (in particular strong links with national public policies). Variables were associated with each criterion in order to transform this theoretical definition into an empirical one that would allow medium-sized cities to be distinguished from large and small cities in the French urban system.

The first criterion of definition (intermediate position in the urban hierarchy) was estimated by setting thresholds on the 2016 population of urban areas. The goal is to measure demographic thresholds that are specific to mediumsized cities and reflect their in-betweenness in the urban hierarchy. The French urban hierarchy respects the rank-size law, and is therefore characterised by a pyramidal shape (or Christallerian organisation) with very few large cities, numerous small cities, and medium-sized cities in between (Pumain/Moriconi-Ebrard 1997: 307). This shape makes indicators such as the mean or the median unsuitable for choosing thresholds for medium-sized cities, as these cities are not positioned in the 'middle' of the urban hierarchy, 
Table 1 Variables used in cluster analyses

\begin{tabular}{lll}
\hline & Socio-economic classification & Demographic evolution classification \\
\hline Source & Insee, general census of the population of 2016 & Insee, general censuses of the population of 1975, 1982, \\
& & $1990,1999,2006,2011,2016$ \\
Variables & Demographic trajectories between 1975 and 2016: se- \\
& quences of six intercensal periods (1975-1982, 1982- \\
& $1990,1990-1999,1999-2006,2006-2011,2011-2016)$ \\
\hline
\end{tabular}

but closer to the top. Thus, thresholds were chosen using the observation of a rank/size graph to locate medium-sized cities (see Figure 1). More precisely, a rank size diagram of French urban areas with a non-logarithmic scale was used. The cloud of dots forms a curve that reflects the pyramidal shape of the urban system. The vertical part of the curve is constituted by numerous close dots, which are small cities; the horizontal part is formed by a few distinct dots, which are large cities. In between, the turn of the curve gathers medium-sized cities. A multi-linear regression was utilised to precisely locate the breaks in the curve, particularly around this turn. This method allowed demographic thresholds to be set for medium-sized cities. Urban areas with a demographic weight situated between 37,300 and 146,900 inhabitants were considered as occupying an inbetween position in the urban hierarchy that characterises medium-sized cities.

The centrality and influence of cities on their surroundings was measured through the diversity of facilities and infrastructure they provide. This diversity was captured using the Permanent Database of Facilities and Equipment of 2018 (Base permanente des équipements), with indicators to measure the diversity of facilities within each French urban area. The database distinguishes three different ranges of facilities according to their occurrence within French municipalities: local, intermediate and superior. It gathers information about the services, shops or infrastructure located in each French municipality. An indicator that measures the diversity of facilities in each range was built, and thresholds were set to distinguish high levels of diversity from lower levels.

Finally, the link to public policies and the importance of discourses which participated in creating the category of medium-sized cities in France were integrated in the definition with a variable indicating whether urban areas have benefited from at least one of the two national programmes aimed at medium-sized cities since the 1970s. ${ }^{3}$ These three variables were combined to select medium-sized cities from among French urban areas (see Figure 2). With this definition of medium-sized cities, French urban areas could be

\footnotetext{
3 The programme Action Cœur de Ville (2017) and the Contrats de villes moyennes (1973).
}

divided in three groups: 30 large cities, 166 medium-sized cities, and 575 small cities.

\subsection{A combination of two cluster analyses to qualify the demographic evolution and socio-economic composition of French urban areas}

Secondly, two classifications were conducted on French urban areas' subsets, in order to qualify their socio-economic composition and their demographic evolution. The socioeconomic classification clusters subsets according to their socio-economic composition in 2016, using multivariate analysis methods. The variables chosen for this classification were those that differed more strongly between observations. Unemployment was selected to capture the local economic situation with a synthetic indicator, and three out of the six groups of the standard occupational classification $^{4}$ of the French national institute of statistics (Insee) were selected (see Table 1). For this classification, the hierarchical clustering analysis was applied to the coordinates of a principal component analysis in order to reduce the dimensionality of the dataset and get more optimal clusters. Ward's clustering method was used, with Euclidian distance as a similarity measure. The results were then consolidated using the PAM (Partitioning Around Medoids) method. ${ }^{5}$

The demographic evolution classification groups statistical items according to their demographic trajectories. ${ }^{6}$ The demographic trajectories are sequences of states (growth, stagnation or demographic decline ${ }^{7}$ ) during six intercensal periods from 1975 to 2016. Optimal matching methods were used to compare sequences and build a distance

\footnotetext{
${ }^{4}$ Nomenclature des professions et catégories socioprofessionnelles.

${ }^{5}$ Weighted cluster package on $\mathrm{R}$.

6 TramineR package on $\mathrm{R}$.

7 For each population census, the average annual growth rates were used to determine these states. Following most work about demographic decline, statistical units with growth rates of less than $-0.1 \%$ /year over a given period were classified as declining, those with a rate above $0.1 \% /$ year were considered to be increasing, and those with a rate between $-0.1 \% /$ year and $0.1 \% /$ year were considered to be stagnating.
} 
matrix. ${ }^{8}$ A hierarchical clustering analysis with Ward's method was then conducted.

For both classifications, the method is designed to account for the homogeneity or heterogeneity of French urban areas $^{9}$ (delimitations of 2010). The aim is to capture the differences that can exist within urban areas, as the literature about urban shrinkage and city centre devitalisation shows that strong contrasts can exist between the core and peripheries of urban areas. To do so, each urban area was separated in three subsets ${ }^{10}$, following the work of Cauchi-Duval, Cornuau and Rudolph (2017): the central municipality, the banlieue (close suburbs around the central municipality - together, they form the urban core of the urban area), and the peripheries. This division allows the testing of the hypothesis that there was stronger decline of urban centres in some medium-sized cities. To capture the characteristics of city centres, observing variables at the intra-municipal level would have been better, but this would have made the analysis much more complicated as no official limits for city centre districts exist in France. Therefore, the level of the central municipality is a good compromise, as the data is easy to access and this approach still allows a close approximation of the location of the city centre district. Indeed, French territory is divided into more than 34,000 municipalities, which cover particularly small areas in comparison with other countries. Therefore, the city centre district often concentrates the majority of the population within the central municipality.

For both classifications, the results obtained allow the urban areas' subsets (central municipalities, banlieues and peripheries) to be categorised in different clusters, according to their socio-economic composition and demographic trajectory. However, our goal was to qualify the urban areas as a whole. Therefore, sequence analyses were conducted to identify the most common sequences of clusters within urban areas, and to group those which were similar. This allowed to elaborate more readable and synthetic results at the urban area level, while still taking the heterogeneity of urban areas into consideration (see Figure 3).

Eventually, the clusters of these two typologies were intersected for medium-sized cities in order to create a unique

\footnotetext{
8 TramineR package on R. Constant costs were used to calculate these distances.

9 An urban area is a functional delimitation of cities created by the French national institute of statistics and economic studies (Insee). An urban area is a group of contiguous municipalities, encompassing an urban core providing at least 1,500 jobs (the urban unit), surrounded by peripheries, among which at least $40 \%$ of the employed resident population works in the urban core.

10 Created using the categorisation of the French national institute of statistics and economic studies.
}

classification that synthesises the most common combinations of demographic and socio-economic classes.

\section{Results}

\subsection{The socio-economic classification}

In this classification, unemployment rates tended to be quite independent from other variables, which is why a partition was necessary in a high number of classes to obtain the most robust results. A partition in eight clusters was chosen for this reason (see Figure 4).

This high number of classes allows some clusters that are relevant for the analysis to be isolated, and other clusters to be grouped together. As a result, a partition was adopted in four classes (see Table 2). The socially privileged class gathers together clusters 1 and 2 . The mixed and socially diversified class gathers clusters 3,5 and 6 . It groups together a socially mixed cluster (cluster 3 , which includes subsets with close to average rates for workers, intermediate professionals, and executive staff and highly educated professionals) and two clusters characterised by strong social specialisations (in clusters 5 and 6, workers and intermediate professionals are respectively overrepresented). These clusters have lower than average unemployment rates in common. Cluster 4 was treated on its own, as a fragile class, where the share of workers, executive staff/ highly educated professionals and intermediate professionals is close to average, but the unemployment rate is high (15\% in this class, compared to an average of $12 \%$ for all statistical items). Finally, a pauperised class was created by grouping the classes 7 and 8 , which are characterised by overrepresentations of workers, underrepresentations of executive staff, and high unemployment rates (on average $15 \%$ in cluster 7 and $22 \%$ in cluster 8 ).

These profiles are heterogeneously distributed amongst urban areas. Figure 5 shows that the more socially privileged type is predominant in large cities, rather present in medium-sized cities, and uncommon in small cities. In medium-sized cities, we notice important contrasts between the subsets of urban areas: whereas the fragile and pauperised types are predominant amongst central municipalities, privileged and mixed or socially diversified profiles prevail in more peripheral subsets. Finally, four synthetic classes defining the medium-sized urban areas' socio-economic composition and spatial organisation were created in order to take into account these contrasts between central municipalities, banlieues and peripheries (see Table 3). 
Step 1

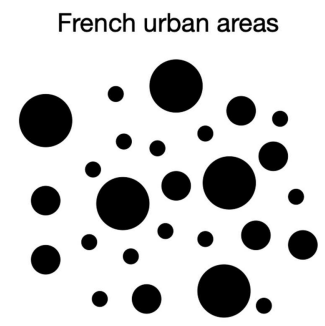

Classification 1 socio-economic

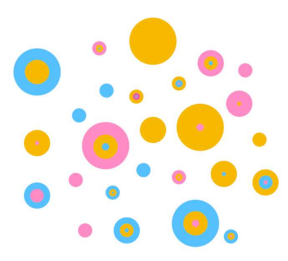

Level of analysis

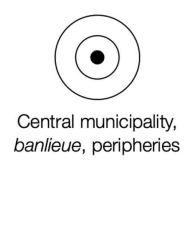

Classification 2

demography

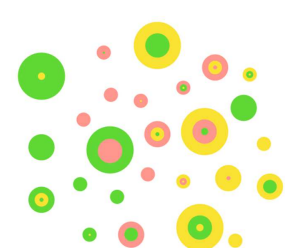

Step 2

Medium-sized cities
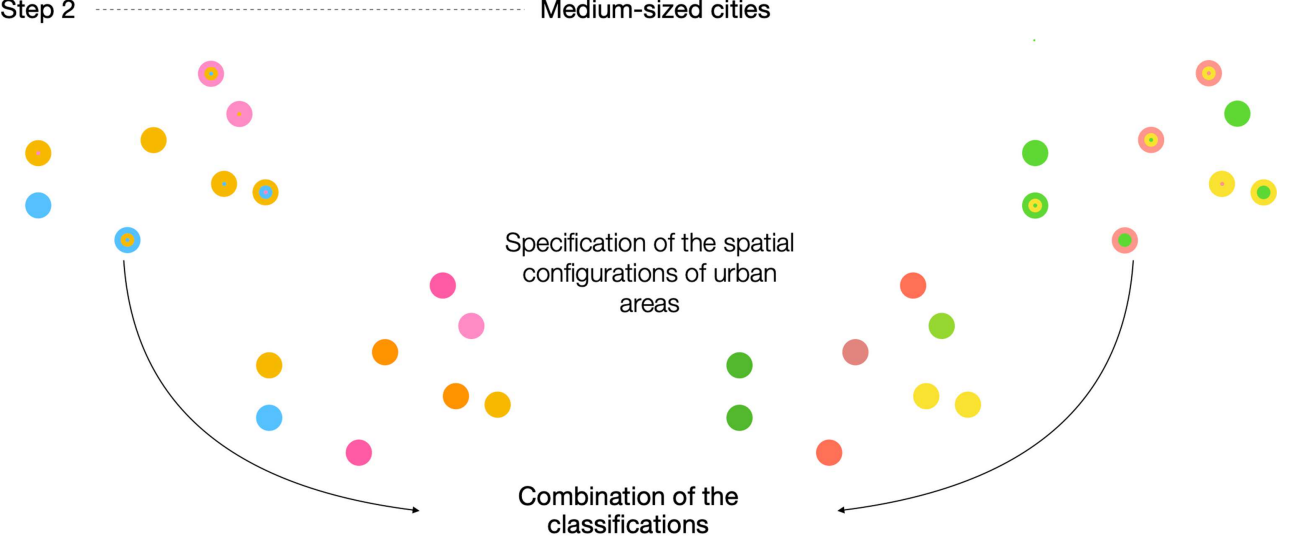
classifications

C1 C2

MSC a

$\mathrm{MSC} b$

MSC c

O

$\downarrow$

Synthetic socio-eco-demographic

classification of medium-sized cities

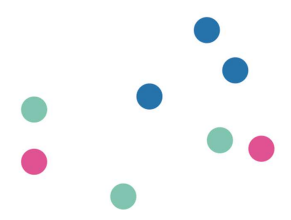

Figure 3 Diagram of the classification method adopted 


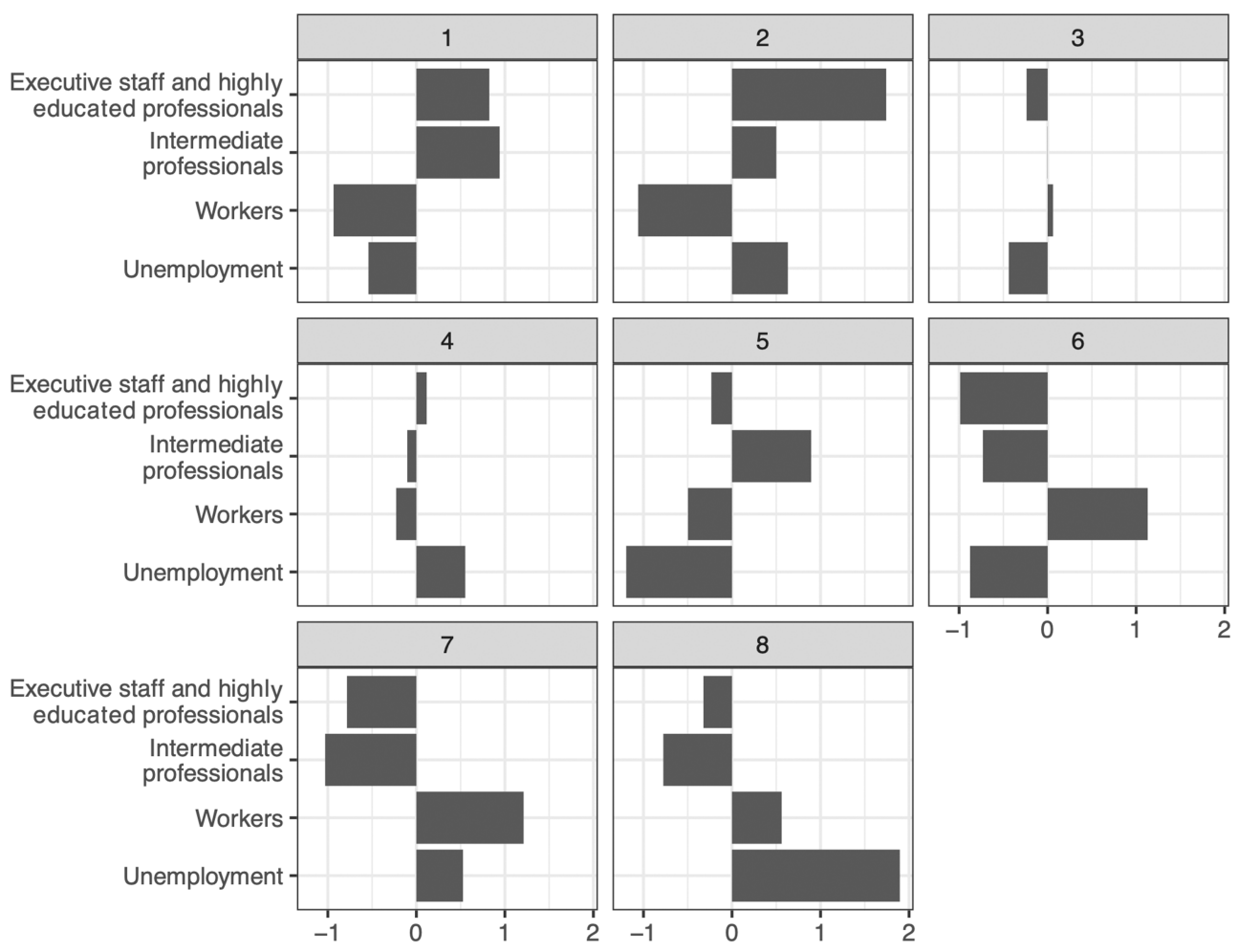

Figure 4 The socio-economic classification clusters Source: Census of the French national institute of statistics (2016, Insee)

Table 2 Clusters resulting from the demographic classification Privileged Cluster 1 Cluster 2

Mixed or diversified profiles

Cluster 3

Cluster 5

Cluster 6

Fragile

Pauperised

Cluster 4

Cluster 7

Cluster 8

\subsection{The demographic evolution classification}

The second classification allowed subsets of urban areas to be distinguished according to their demographic trajectory. A division in five clusters was chosen (see Figure 6). Then, in order to make the analysis more readable, the types of most interest for the research question were isolated and others were grouped to obtain a partition into four groups (see Table 4). Cluster 1 was isolated and includes statistical items with growth trajectories. Clusters 2 and 4 were grouped together as both of them include mixed trajectories. Indeed, cluster 2 corresponds to slower growth trajectories: over the last intercensal period (2011-2016), $50 \%$ of the headcount of this cluster was affected by demographic decline but with low average losses (-0.15\%/year). Cluster 4 groups items with trajectories of interrupted demographic decline. Cluster 3 groups urban areas' subsets with trajectories of demographic decline since 1975 or 1982 . Cluster 5 includes trajectories with alternating periods of stagnation and decline, or recent decline (since 2006).

In this second analysis, we note more similarities between large cities, medium-sized cities and small cities than in the socio-economic cluster analysis (see Figure 7). However, small cities are distinguishable because of their low share of subsets with trajectories of demographic growth. The central municipalities of medium-sized cities are also noticeable, as $60 \%$ of them belong to the decline or stagnation/recent decline clusters. The banlieues and outer peripheries of medium-sized cities are less affected by this phenomenon. Finally, four classes were created to define the demographic trajectories of medium-sized cities' urban areas and their spatial heterogeneity (see Table 5).

\subsection{The final typology of medium-sized cities}

The sixteen possible combinations of the two classifications and their distribution amongst medium-sized cities are represented in Figure 8. The analysis of this diagram guided us in elaboration of the final typology, presented in Table 6. More than $70 \%$ of medium-sized cities can be considered as being in decline, and two main situations appear. Some 

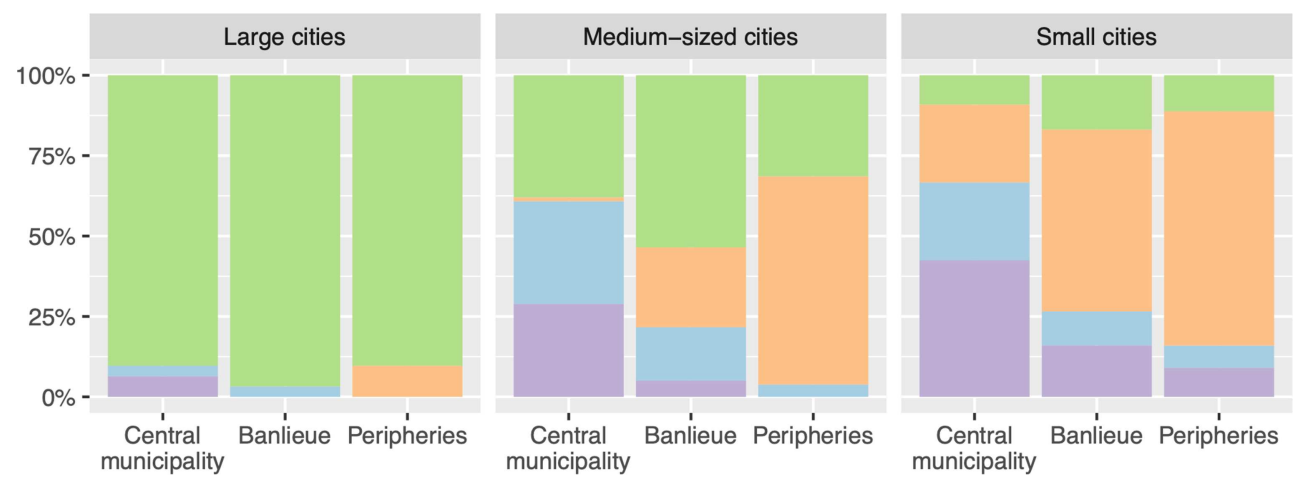

Privileged

Mixed and diversified

Fragile

Pauperised

Figure 5 Distribution of the socio-economic classification's clusters amongst large, medium-sized and small cities' subsets

Source: Census of the French national institute of statistics (2016, Insee)

Table 3 Final clusters for the socio-economic classification of medium-sized cities

\begin{tabular}{ll}
\hline Clusters & Characteristics \\
\hline Mostly fragile or pauperised & $\begin{array}{l}\text { Urban areas with at least two subsets classified as fragile or pauperised } \\
\text { Pauperisation limited to the central municipality } \\
\text { Urban areas with a pauperised central municipality, peripheral subsets are mixed/ } \\
\text { socially diversified or privileged }\end{array}$ \\
Mostly privileged or mixed & $\begin{array}{l}\text { Urban areas with a fragile central municipality, peripheral subsets are mixed/ } \\
\text { socially diversified or privileged } \\
\text { Urban areas with at least two subsets mixed or privileged }\end{array}$ \\
\hline
\end{tabular}

urban areas are strongly affected by demographic and socioeconomic difficulties: at least two out of the three subsets (central municipality, banlieue or peripheries) are affected. We decided to name these types 'urban shrinkage', as their characteristics are in line with the results of research about shrinking cities in France (demographic losses, high rates of unemployment, pauperisation of residents). In some urban areas, markers of decline are only present in the central municipality, but not in the close or outer suburbs: we decided to name these types 'urban decline of the centre', which can be more or less intense. This group of cities are likely to be affected by city centre devitalisation, as they are characterised by a pauperisation of their residents and demographic losses, but only in their centres. However, this result should be confirmed with analysis involving more variables, as city centre devitalisation is also characterised by other factors, such as commercial or housing vacancies.

Explorations of time series datasets allowed some specificities of these profiles to be highlighted. On average, urban areas affected by severe or limited urban shrinkage are characterised by very high rates of workers in the late 1960s, which suggests they were industrialised during the Fordist era. Moreover, these cities have displayed markers of decline ${ }^{11}$ since 1975. These specificities are not found amongst cities affected by a decline of the centre, where social structure is on average more similar to growing and socially privileged cities. In these cities, the markers of decline have appeared more recently (between 1999 and 2006 for most variables), and only in the central municipality. The cartography of these profiles also shows differences in their spatial distribution (see Figure 9). Cities affected by urban shrinkage are mostly located in north-eastern France and around the Massif Central. These regions used to feature a concentration of manufacturing plants and mines. This result is therefore in line with other work about shrinking cities, which has stated that such cities are predominantly located in economically fragile regions, often hit by deindustrialisation and isolated from new economic centres (Wolff/Fol/Roth et al. 2013). The geography of urban areas affected by a decline of their centres is rather different, as these cities are dispersed all across the country.

\footnotetext{
11 Such as demographic decline, rise of unemployment rate, social specialisation of the core of the urban area.
} 
1
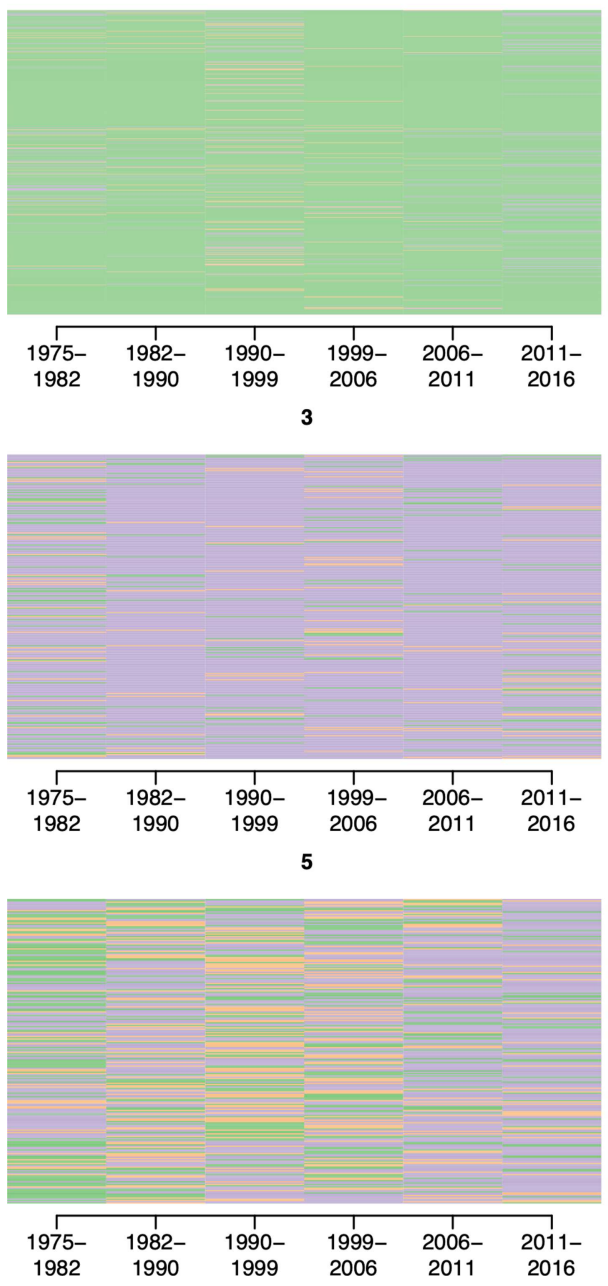

2
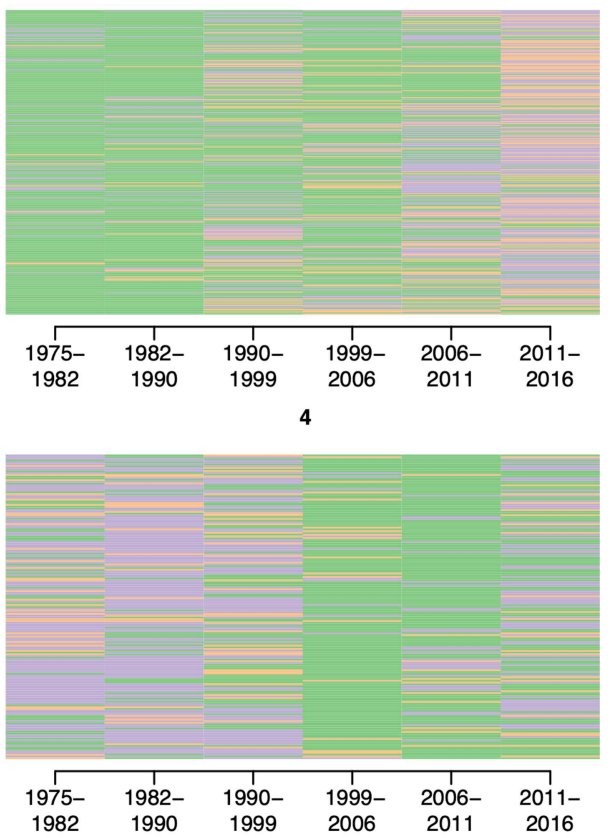

Figure 6 Sequence index plots of the clusters

Source: Censuses of the French national institute of statistics (Insee)

Note: Sequence index plots allow the visualisation of all the trajectories of the items of the clusters

\section{Discussion}

\subsection{Medium-sized cities as a specific category amongst French cities?}

As seen above, several studies suggest that small and medium-sized cities tend to be more fragile than large ones (Cauchi-Duval/Cornuau/Rudolph 2017; Baudet-Michel/ Conti/Chouraqui et al. 2019). The results presented in this paper support this idea: in both cluster analyses, large cities display the highest shares of growing or socially privileged clusters (see Figures 5 and 7). These differences between large and smaller cities are often explained by globalisation and metropolisation processes, which have reinforced the agglomeration of people, economic activities and wealth in metropolises and their regions (Scott/Storper 2003). Some large cities therefore become "centres of command and control" in globalised networks (Amin/Graham 1997: 413; based on Sassen 1991) and concentrate the most strategic economic functions. The development of metropolises may therefore overshadow smaller cities, whose economic specialisation and position within global networks are less favourable (Martinez-Fernandez/Audirac/Fol et al. 2012; Wolff/Fol/Roth et al. 2013). In France, the focus of territorial public policies on metropolises in the last ten years and the reorganisation of public services in favour of more concentration in larger cities enhance these tendencies, and can also explain the contrasts between large and smaller cities (Berroir/Fol/Quéva et al. 2019). This tendency is more generally observable in other countries (Kühn 2015; Lang 2015; Roth 2016). Scholars who focus on peripheralisation and polarisation processes in the European Union indeed underline that the reinforcement of metropolitan areas and their regions is a preferred policy to 
Table 4 Clusters resulting from the demographic classification

Growth Cluster 1

Mixed trajectories

Cluster 2

Cluster 4

Stagnation and recent decline

Cluster 5

Decline

Cluster 3

enhance European competitiveness at the international level (Lang/Henn/Ehrlich et al. 2015). If they are not compensated by spatial development policies for other territories, such policies that accompany and advantage already polarised regions can reinforce existent regional disparities. In France, territorial public policies followed these tendencies. The focus on re-equilibrium and territorial equity has become progressively less significant, and spatial policies favouring competitiveness have gained more and more importance (Santamaria 2012; Artioli 2017). This search for competitiveness led to the implementation of excellence policies targeted towards larger cities, with the goal of promoting their inclusion and position within global economic networks. Small and medium-sized cities, which used to be targeted and supported by public policies, seem to be disqualified in these pro-competitiveness strategies (Santamaria 2012). The emergence of a new public policy that targets medium-sized cities in 2017 could, however, change this tendency.

The heterogeneity of medium-sized cities' urban areas may, however, differentiate this kind of city from large and small ones. On average, the central municipalities of medium-sized cities are most affected by demographic de- cline, and they display the strongest rise in unemployment rate since 1968, in comparison with the subsets of large or small cities' urban areas. Moreover, our results show that more than $56 \%$ of medium-sized cities face some difficulties in their central municipalities, but not in their peripheries. Thus, markers of decline seem to be more concentrated in central municipalities in medium-sized cities than in other types of cities. This configuration exists in small cities but to a lesser extent, as the peripheral subsets of small cities' urban areas are also affected by decline. In medium-sized cities, banlieue and the outer peripheries are very rarely classed in the most fragile clusters of both socio-economic and demographic classifications (see Figure 5 and 7).

This spatial organisation could be explained by urban sprawl, which may have impacted medium-sized cities specifically. Indeed, in France urban sprawl started during the 1960s in large cities, and in other cities after 1970 (Haran/Garnier 2018: 28-29). Such suburbanisation may provoke a pauperisation and demographic decline of urban cores, because of the departure of middle and upper classes who are able to access homeownership in the peripheries. This contrast between declining centres and privileged peripheries is rarely observed in France's largest cities, as the results presented here and other research show. Cusin (2016) indeed analyses French urban areas' socio-spatial organisation by using real estate prices, and shows that the largest French cities ${ }^{12}$ are predominantly characterised by higher prices in their centres and lower prices in their

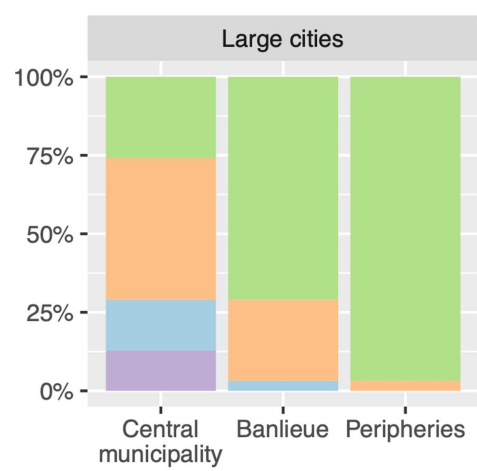

Growth

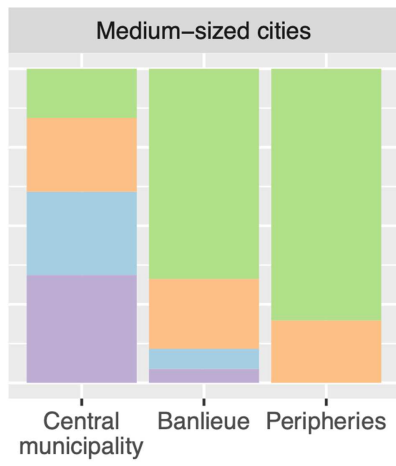
municipality

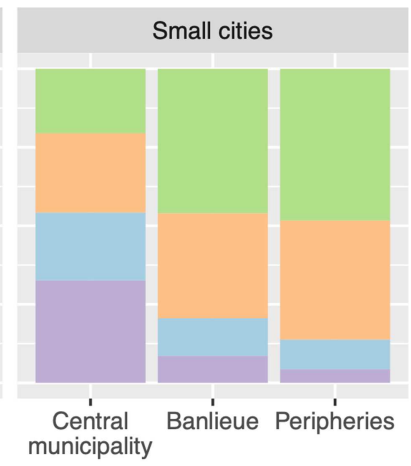

municipality

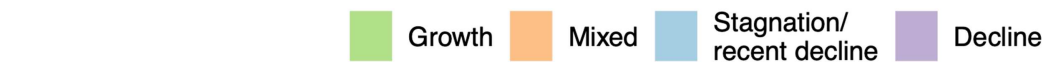

Figure 7 Distribution of the demographic classification's clusters amongst large, medium-sized and small cities' subsets

Source: Census of the French national institute of statistics (2016, Insee)

12 Paris, Bordeaux, Lyon, Nantes, Toulouse, Strasbourg, Rennes.

13 According to the definition used in this paper. 
Table 5 Final clusters for the demographic classification of medium-sized cities

\begin{tabular}{ll}
\hline Profiles & Characteristics \\
\hline Mostly declining or stagnant & $\begin{array}{l}\text { Urban areas with at least two subsets in demographic decline or alternating de- } \\
\text { cline and stagnation }\end{array}$ \\
$\begin{array}{l}\text { Demographic decline limited to the central mu- } \\
\text { nicipality }\end{array}$ & $\begin{array}{l}\text { Urban areas with a central municipality in demographic decline, peripheral subsets } \\
\text { growing or mixed }\end{array}$ \\
$\begin{array}{l}\text { Demographic decline or stagnation limited to } \\
\text { the central municipality }\end{array}$ & $\begin{array}{l}\text { Ulternate, peripheral subsets are growing or mixed } \\
\text { Mostly growing }\end{array}$ \\
\hline
\end{tabular}

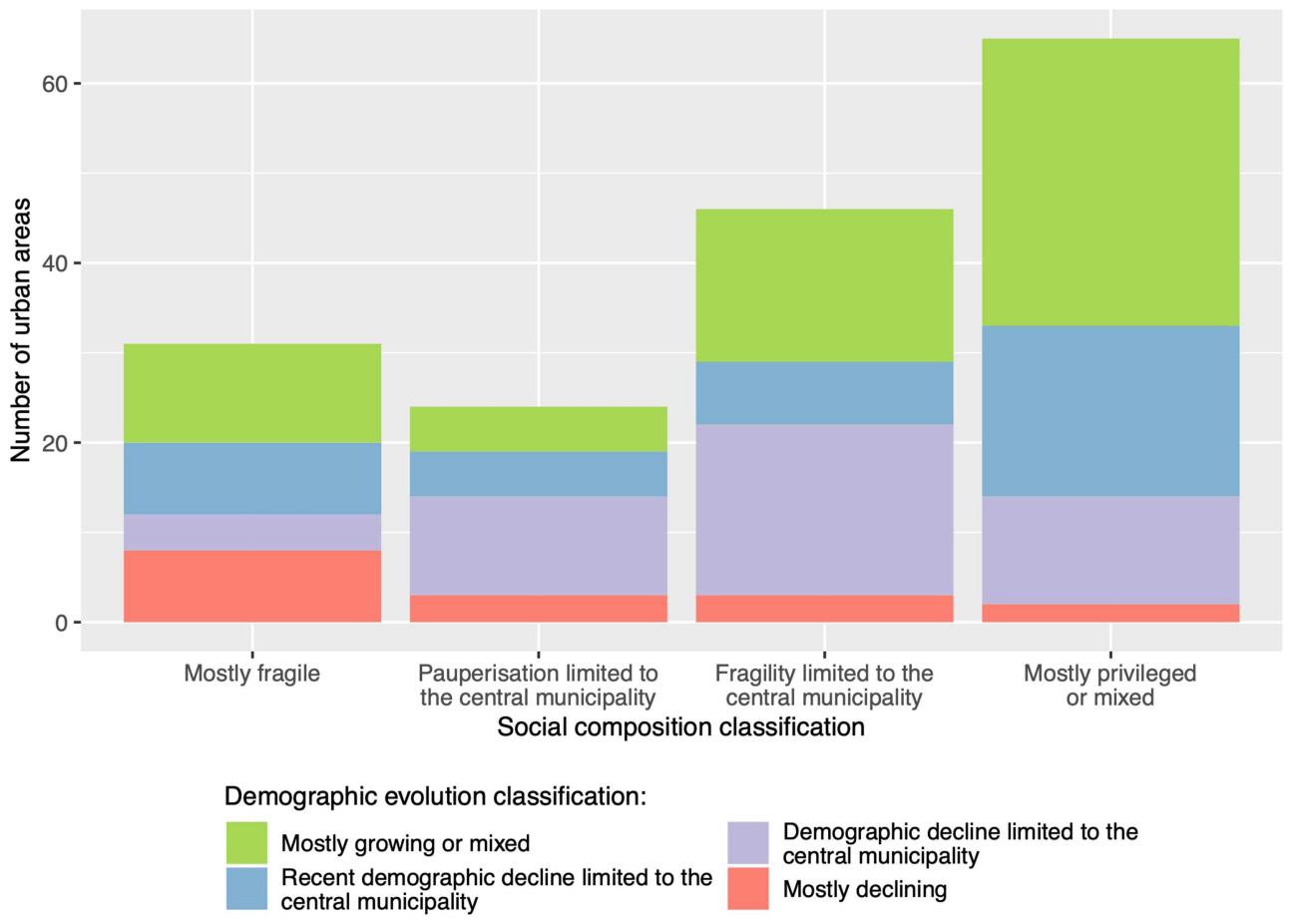

Figure 8 Histogram: intersection of the socio-economic and demographic classifications Source: Censuses of the French national institute of statistics (Insee)

Note: This diagram visualises how the two classifications intersect. Each bar represents a class of the socio-economic classification. These bars are coloured according to the proportion of urban areas assigned to the four classes of the demographic classification

peripheries, while only one large city ${ }^{13}$ displays a reversed situation (Aix-Marseille). This can be explained by the gentrification dynamics that occurred in many large cities from the 1990s onward (Chabrol/Collet/Giroud et al. 2016). The results presented in this paper suggest that this process has not affected medium-sized cities in the same way, as the central municipalities are less socially privileged than the peripheries in the majority of medium-sized cities. This result echoes the work of Guéraut (2018) about the dynamics of decline in the urban cores of medium-sized cities, which seem to be more affected by pauperisation processes than by gentrification.

To sum up, medium-sized cities are not specific amongst French cities in terms of decline dynamics, because they share similarities with small cities, which also display mark- ers of decline. At the same time, medium-sized cities seem to be specific in their socio-spatial configuration, as pauperisation and demographic decline of their centres affect a majority of them.

\subsection{French medium-sized cities in decline: between urban shrinkage and devitalisation of the city centre}

The results allow a distinction to be drawn between the devitalisation of city centres, on the one hand, and urban shrinkage, on the other hand. So far, the distinction between urban shrinkage and city centre devitalisation has been unclear. First, they have mainly been studied separately. Indeed, most government or institutional reports about medium- 
Table 6 Clusters resulting from a combination of the socio-economic and demographic classifications for medium-sized cities

\begin{tabular}{|c|c|c|c|}
\hline \multirow[t]{2}{*}{ Profiles } & \multicolumn{2}{|l|}{ Combinations } & \multirow{2}{*}{$\begin{array}{l}\text { Share amongst } \\
\text { medium-sized cities }\end{array}$} \\
\hline & Demographic classification & Socio-economic classification & \\
\hline $\begin{array}{l}\text { Severe urban } \\
\text { shrinkage }\end{array}$ & Mostly declining & Mostly fragile & $4.8 \%$ \\
\hline \multirow[t]{4}{*}{$\begin{array}{l}\text { Spatially limited } \\
\text { urban shrinkage }\end{array}$} & $\begin{array}{l}\text { Demographic decline limited to the central } \\
\text { municipality }\end{array}$ & Mostly fragile & $10.8 \%$ \\
\hline & $\begin{array}{l}\text { Demographic decline or stagnation limited } \\
\text { to the central municipality }\end{array}$ & Mostly fragile & \\
\hline & Mostly declining or stagnant & $\begin{array}{l}\text { Pauperisation limited to the central mu- } \\
\text { nicipality }\end{array}$ & \\
\hline & Mostly declining or stagnant & $\begin{array}{l}\text { Fragility limited to the central municipal- } \\
\text { ity }\end{array}$ & \\
\hline \multirow{4}{*}{$\begin{array}{l}\text { Intense urban } \\
\text { decline of the } \\
\text { centre }\end{array}$} & $\begin{array}{l}\text { Demographic decline limited to the central } \\
\text { municipality }\end{array}$ & $\begin{array}{l}\text { Pauperisation limited to the central mu- } \\
\text { nicipality }\end{array}$ & $25.3 \%$ \\
\hline & $\begin{array}{l}\text { Demographic decline limited to the central } \\
\text { municipality }\end{array}$ & $\begin{array}{l}\text { Fragility limited to the central municipal- } \\
\text { ity }\end{array}$ & \\
\hline & $\begin{array}{l}\text { Demographic decline or stagnation limited } \\
\text { to the central municipality }\end{array}$ & $\begin{array}{l}\text { Pauperisation limited to the central mu- } \\
\text { nicipality }\end{array}$ & \\
\hline & $\begin{array}{l}\text { Demographic decline or stagnation limited } \\
\text { to the central municipality }\end{array}$ & $\begin{array}{l}\text { Fragility limited to the central municipal- } \\
\text { ity }\end{array}$ & \\
\hline \multirow{4}{*}{$\begin{array}{l}\text { Low intensity } \\
\text { urban decline of } \\
\text { the centre }\end{array}$} & $\begin{array}{l}\text { Demographic decline limited to the central } \\
\text { municipality }\end{array}$ & Mostly privileged or mixed & $31.9 \%$ \\
\hline & $\begin{array}{l}\text { Demographic decline or stagnation limited } \\
\text { to the central municipality }\end{array}$ & Mostly privileged or mixed & \\
\hline & Mostly growing or mixed & $\begin{array}{l}\text { Pauperisation limited to the central mu- } \\
\text { nicipality }\end{array}$ & \\
\hline & Mostly growing or mixed & $\begin{array}{l}\text { Fragility limited to the central municipal- } \\
\text { ity }\end{array}$ & \\
\hline $\begin{array}{l}\text { Growing and so- } \\
\text { cially privileged }\end{array}$ & Mostly growing or mixed & Mostly privileged or mixed & $19.3 \%$ \\
\hline \multirow[t]{2}{*}{ Atypical } & Mostly growing or mixed & Mostly fragile & $7.8 \%$ \\
\hline & Mostly declining & Mostly privileged or mixed & \\
\hline
\end{tabular}

sized cities focus on the commercial devitalisation of city centres. Their analyses are limited to shop vacancies and conducted at intra-municipal levels (CGEDD/IGF 2016; Bouvier/Madry 2017; Pointereau/Bourquin 2017). Because of this specific focus, urban shrinkage is not mentioned in such reports. Scholars interested in the weakening of some medium-sized cities have mainly focused on urban shrinkage or urban decline. But after 2014, the growing tendency towards the devitalisation of city centres has been taken into account by some academics, who try to integrate this issue into their work and link it with urban shrinkage. In particular, the work of Baudet-Michel, Berroir, Fol et al. (2017) was the first to combine this notion with city centre devitalisation. Their work shows how the devitalisation of city centres can be a symptom of a more structural crisis affecting shrinking cities. This conclusion is in line with the majority of studies about urban shrinkage in France. Indeed, numerous previous studies show that the multidimensional crisis that characterises urban shrinkage is more intense in urban cores, which concentrate a poorer population, more significant population losses and more degradations of the urban environment (housing and retail vacancies, deterioration of buildings) than the peripheral areas (Fol 2012; Miot 2012; Wolff/Fol/Roth et al. 2013; Cauchi-Duval/Béal/ Rousseau 2016). City centre devitalisation can therefore be considered as a manifestation of urban shrinkage; the two phenomena can overlap.

The results of this study show these two processes could also exist separately, as they are different in several ways. Indeed, medium-sized cities affected by urban shrinkage are characterised by an important fragility of their city centres, but other parts of the urban areas are also affected. This type of city is concentrated in a few regions. These cities have faced difficulties for a long time, with 1975 as a key date where markers of decline appeared. On average, such cities display a specificity in their social composition, with high rates of workers at the end of the 1960s (on average $48 \%$, 


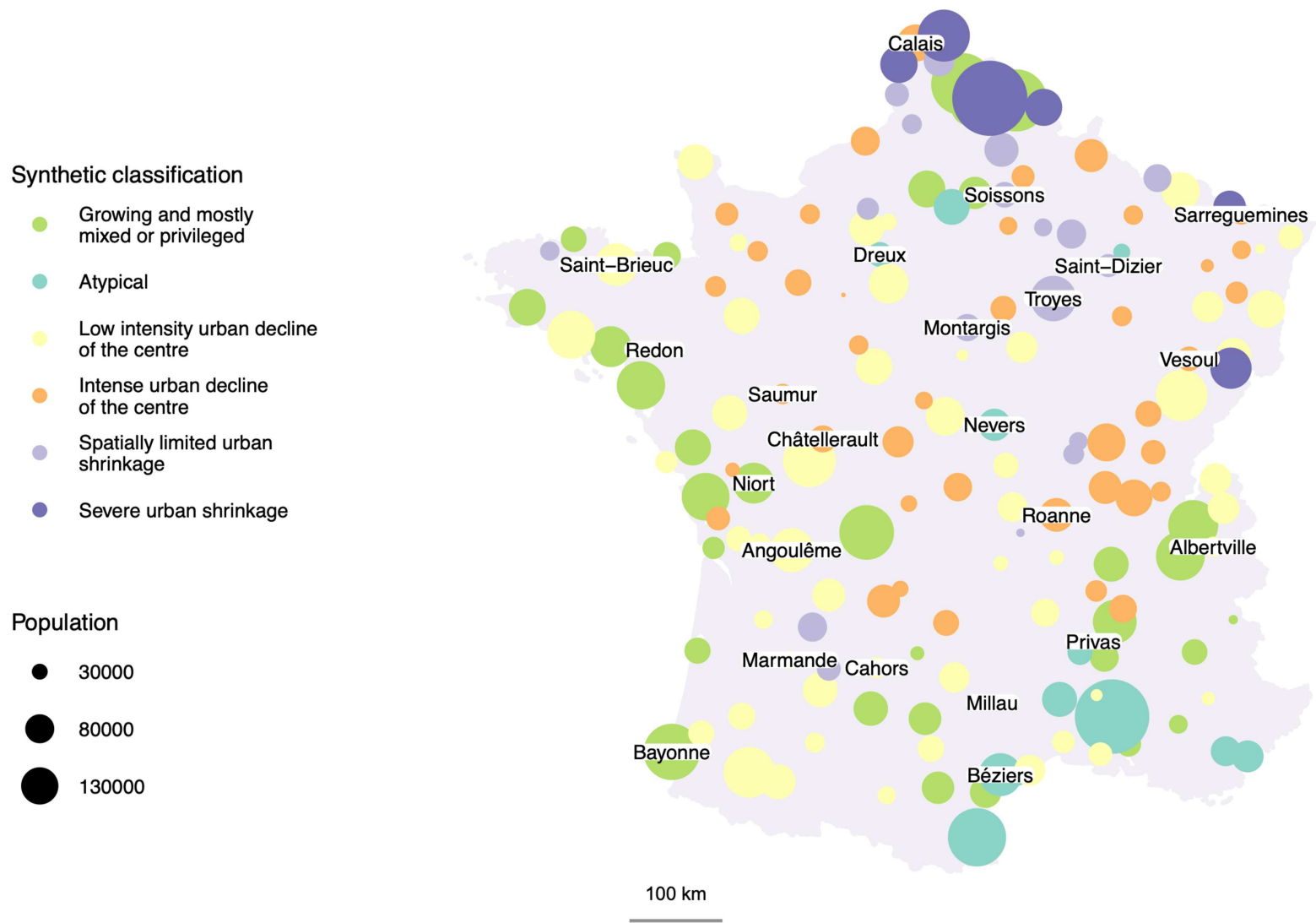

Figure 9 Map of the clusters of the synthetic socio-economic-demographic classification of French medium-sized cities Source: Censuses of the French national institute of statistics (Insee)

Geographical data: OpenStreetMap, available under the Open Database License, @ OpenStreetMap contributors

compared to $40 \%$ for medium-sized cities ${ }^{14}$ ), a particularity that still distinguishes them from other medium-sized cities today. ${ }^{15}$ These elements suggest that many of these cities are industrial cities that developed during the Fordist era but have faced difficulties since the 1970s.

Medium-sized cities affected by city centre devitalisation are characterised by distinct features. First, difficulties are restricted to the central municipality, and increased strongly at the turn of the 2000s. Second, these cities are distributed throughout France and are not concentrated in particular regions. They do not display a specific social composition either. It can therefore be hypothesised that this form of urban decline is specific, as its temporality and geography differs from urban shrinkage. Such city centre devitalisation dynamics could be linked to the economic turmoil of 2008 which may have induced a pauperisation of fragile house- holds living in city centres. A second wave of suburbanisation, particularly strong in medium-sized cities, is also observable at the turn of the 2000s (Haran/Garnier 2018: 28 ) and may have increased the demographic decline and pauperisation of medium-sized cities' centres in the $2000 \mathrm{~s}$ and 2010s.

These results therefore suggest that the two phenomena can be differentiated and are characterised by their own specificities. Other analyses could complete these results and allow the two phenomena to be distinguished more precisely. In particular, using data about the degradation of the urban environment seems pertinent. Case studies and field work could also improve knowledge about similarities and differences between these two processes and their history. International comparisons could also help to enhance understanding of the two processes.

\footnotetext{
14 Insee, Population census of 1968.

15 Insee, census of 2016.
} 


\section{Conclusion and public policy perspectives}

This work shows the heterogeneity of medium-sized cities, a category which includes cities facing an important crisis, cities with spatially limited fragilities, and some with few or no markers of decline at all. The weakness of the central areas of medium-sized cities is also noticeable, as more than half of medium-sized cities display markers of fragility in their central municipality but not elsewhere in their urban area. These results suggest that the strong focus on city centre revitalisation in French public policies is pertinent. Indeed, several case studies of French medium-sized cities (Alençon, Périgueux, Douai, Lens, Saint-Brieuc, Roanne) reveal that local public policies aiming to revitalise the city centre have been implemented since the 2010s. These revitalisation strategies share several common features. Firstly, a strong focus on residential attractiveness is observable, as the main objective of the policies adopted in these six medium-sized cities is to attract new residents and visitors to the city centre. Secondly, the revitalisation projects are multisectoral, and systematically include public space remodelling and housing improvement actions. The development of cultural infrastructure and support for shopkeepers are other common measures (Gauthier 2016; Dinh 2018; Frel-Cazenave 2019; Lledo 2019).

These few examples suggest that city centre revitalisation models circulate between medium-sized cities, offering a standardised solution for city centre devitalisation. Since 2017, these convergences may well have increased, as the national programme "City Heart Action" became the predominant answer to the difficulties faced in some medium-sized cities in France. This programme provides a total of 5 billion euros of funding, which is allocated to local authorities. To obtain this funding, local authorities must contract with public operators and the state and elaborate a multisectoral revitalisation project for the city centre that includes measures for public spaces, retail, housing, architectural heritage and mobility. Similarities between the revitalisation projects designed as part of this programme have already been observed (Delpirou 2019).

These actions may improve the overall quality of the urban environment in the centre of medium-sized cities. However, the policy standardisation processes that seem to be occurring within medium-sized cities are raising questions. Indeed, city centres appear to be the primary area of focus, multisectoral revitalisation plans are the main mode of operation, and demographic growth is the principal objective of these policies. This homogeneity contrasts with the diversity of medium-sized cities, which has been underlined in this paper. Such revitalisation strategies may not, for example, be sufficient for cities that face urban shrinkage and severe difficulties beyond their centres. Thus, the heterogeneity of medium-sized cities should be acknowledged in public policies, in order to adapt urban planning strategies to this variety of contexts.

Funding information $\mathrm{PhD}$ funded by the Caisse des dépôts et consignation (Banque des territoires, Institut CDC pour la recherche) and the Agence nationale pour la cohésion des territoires.

\section{References}

Adam, B. (2006): Medium-sized cities in urban regions. In: European Planning Studies 14, 4, 547-555. https://doi. org/10.1080/09654310500421220

Amin, A.; Graham, S. (1997): The Ordinary City. In: Transactions of the Institute of British Geographers 22, 4, 411429. https://doi.org/10.1111/j.0020-2754.1997.00411.x

Artioli, F. (2017): Les politiques du retrait territorial de l'État: Réformes de la carte militaire et gestion des mobilisations locales (1989-2012). In: Gouvernement et Action Publique 1, 6, 81-106. https://doi.org/10.3917/gap. 171.0081

Barczak, A.; Hilal, M. (2017): Quelle évolution de la présence des services publics en France? In: Courcelle, T.; Fijalkow, Y.; Taulelle, F. (eds.): Services publics et territoires: adaptations, innovations et réactions. Rennes, 31-67.

Baudet-Michel, S.; Berroir, S.; Fol, S.; Quéva, C.; Santamaria, F. (2017): Acteurs et logiques de la rétraction dans les villes moyennes: un regard comparatif à partir des cas de Forbach, Nevers et Vichy. Paris.

Baudet-Michel, S.; Conti, B.; Chouraqui, J.; Commenge, H.; Delage, M.; Guérois, M.; Guiraud, N.; Le Neindre, C.; Madry, P.; Paulus, F.; Pavard, A.; Toutin, G.; Vallée, J.; Fol, S.; Queva, C. (2019): La rétraction des services et commerces dans les villes petites et moyennes: modalités et logiques à l'échelle interurbaine. Paris.

Berroir, S.; Fol, S.; Quéva, C.; Santamaria, F. (2019): Villes moyennes et dévitalisation des centres: les politiques publiques face aux enjeux d'égalité territoriale. In: Belgeo 3. https://doi.org/10.4000/belgeo.33736

Bezes, P. (2009): Réinventer l'État: Les réformes de l'administration française (1962-2008). Paris.

Boutet, A.; Chouraqui, J.; Mauvoisin, M. (2019): Petites centralités. Entre desserrement urbain et dynamiques macro-régionales. Paris.

Bouvier, M.; Madry, P. (2017): La vacance commerciale dans les centres-villes en France. Mesure, facteurs et premiers remèdes. Paris. $=$ Les Cahiers de l'Institut pour la Ville et le Commerce 1.

Buhnik, S. (2018): Comprendre et comparer la dévitalisa- 
tion des commerces et services dans les villes moyennes. Paris.

Cauchi-Duval, N.; Béal, V.; Rousseau, M. (2016): La décroissance urbaine en France: des villes sans politique. In: Espace Populations Sociétés 1. https://doi.org/ 10.4000/eps.6112

Cauchi-Duval, N.; Cornuau, F.; Rudolph, M. (2017): La décroissance urbaine en France: les effets cumulatifs du déclin. In: Métropolitiques, 26 April 2017. https:// metropolitiques.eu/La-decroissance-urbaine-en-Franceles-effets-cumulatifs-du-declin.html (02.11.2020).

CGEDD - Conseil général de l'environnement et du développement durable; IGF - Inspection générale des finances (eds.) (2016): La revitalisation commerciale des centres-villes. Paris.

Chabrol, M.; Collet, A.; Giroud, M.; Launay, L.; Rousseau, M.; Ter Minassian, H. (eds.) (2016): Gentrifications. Paris.

Cunningham-Sabot, E.; Fol, S. (2009): Shrinking cities in France and Great Britain: A silent process? In: Pallagst, K.; Aber, J.; Audirac, I.; Cunningham-Sabot, E.; Fol, S.; Martinez-Fernandez, C.; Moraes, S.; Mulligan, H.; Vargas-Hernandez, J.; Wiechmann, T.; Wu, T. (eds.): The future of shrinking cities: Problems, patterns and strategies of urban transformation in a global context. Berkeley, 1728.

Cusin, F. (2016): Y a-t-il un modèle de la ville française? In: Revue française de sociologie 57, 1, 97-129. https:// doi.org/10.3917/rfs.571.0097

Delpirou, A. (2019): Action cœur de ville: une réponse en trompe l'œil à la crise des villes moyennes? In: Métropolitiques, 28 October 2019. https://metropolitiques eu/Action-coeur-de-Ville-une-reponse-en-trompe-1-oeila-la-crise-des-villes.html (03.11.2020).

Demazière, C. (2017): Le traitement des petites et moyennes villes par les études urbaines. In: Espaces et Sociétés 168-169, 1-2, 17-32.

Dinh, S. (2018): Revitaliser les centres-villes dans les villes moyennes: enjeux et 'bonnes pratiques'. Paris.

Dormois, R.; Fol, S. (2017): La décroissance urbaine en France: une mise à l'agenda difficile. In: Métropolitiques, 27 March 2017. https://metropolitiques.eu/Ladecroissance-urbaine-en-France.html (02.11.2020).

Duroudier, S. (2014): Les divisions socio-spatiales dans les villes intermédiaires des États-Unis. In: L'Espace Géographique 43, 2, 134-147.

ESPON - European Spatial Planning Observation Network (2012): TOWN: small and medium-sized towns in their functional territorial context. Final Report. Luxembourg.

European Commission (1999): European Spatial Development Perspective. Towards Balanced and Sustainable De- velopment of the Territory of the European Union. Luxembourg.

Fol, S. (2012): Urban Shrinkage and Socio-Spatial Disparities: Are the Remedies Worse than the Disease? In: Built Environment 38, 2, 259-275. https://doi.org/10. 2148/benv.38.2.259

Fol, S.; Cunningham-Sabot, E. (2010): "Déclin urbain" et Shrinking Cities: Une évaluation critique des approches de la décroissance urbaine. In: Annales de Géographie 674, 359-383.

Fol, S.; Miot, Y. (2014): Ancrage, mobilités et régénération urbaine: les limites des injonctions politiques. In: Fol, S.; Miot, Y.; Vignal, C. (eds.): Mobilités résidentielles, territoires et politiques publiques. Villeneuve d'Asq, 211228.

Frel-Cazenave, B. (2019): Les stratégies d'action publique locales et nationales de revitalisation des centres de villes moyennes. Paris.

Gauthier, L. (2016): La décroissance urbaine, facteur d'évolution des politiques publiques? L'exemple de Roanne, dans la Loire. Paris.

Guéraut, É. (2018): Ascension et fragilisation d'une petite bourgeoisie culturelle. Une enquête ethnographique dans une ville moyenne en déclin. Paris.

Haran, L.; Garnier, M. (2019): Les mobilités résidentielles en France: Tendances et impacts territoriaux. Rapport de l'Observatoire des Territoires. Paris.

Hospers, G.-J. (2017): People, Place and Partnership: Exploring Strategies to Revitalise Town Centres. In: European Spatial Research and Policy 24, 1, 65-79. https:// doi.org/10.1515/esrp-2017-0004

Katz, B.; Frey, P. (2017): The reality of main street. Washington, DC.

Kühn, M. (2015): Peripheralization: Theoretical Concepts Explaining Socio-Spatial Inequalities. In: European Planning Studies 23, 2, 367-378. https://doi.org/10.1080/ 09654313.2013 .862518

Lang, T. (2012): Shrinkage, Metropolization and Peripheralization in East Germany. In: European Planning Studies 20, 10, 1747-1754. https://doi.org/10.1080/09654313. 2012.713336

Lang, T. (2015): Understanding New Geographies of Central and Eastern Europe. In: Lang, T.; Henn, S.; Ehrlich, K.; Sgibnev, W. (eds.): Understanding Geographies of Polarization and Peripheralization: Perspectives from Central and Eastern Europe and Beyond. New York, 1-21.

Lang, T.; Henn, S.; Ehrlich, K.; Sgibnev, W. (eds.) (2015): Understanding Geographies of Polarization and Peripheralization: Perspectives from Central and Eastern Europe and Beyond. New York.

Lledo, N. (2019): Revitalisation des centres villes des villes moyennes anciennement industrielles: processus de dévi- 
talisation et stratégies de revitalisation. Etude du cas Alençonnais. Paris.

Lestoux, D. (2017): Revitaliser son coeur de ville: l'adapter au commerce de demain. Voiron.

Martinez-Fernandez, C.; Audirac, I.; Fol, S.; CunninghamSabot, E. (2012): Shrinking Cities: Urban Challenges of Globalization. In: International Journal of Urban and Regional Research 36, 2, 213-225. https://doi.org/10.1111/ j.1468-2427.2011.01092.x

Martinez-Fernandez, C.; Weyman, T.; Fol, S.; Audirac, I.; Cunningham-Sabot, E.; Wiechmann, T.; Yahagi, H. (2016): Shrinking cities in Australia, Japan, Europe and the USA: From a global process to local policy responses. In: Progress in Planning 105, 1-48. https:// doi.org/10.1016/j.progress.2014.10.001

Miot, Y. (2012): Face à la décroissance urbaine, l'attractivité résidentielle? Le cas des villes de tradition industrielle de Mulhouse, Roubaix et Saint-Etienne. Lille.

Oswalt, P.; Rieniets, T. (eds.) (2006): Atlas of Shrinking Cities. Ostfildern.

Pointereau, R.; Bourquin, M. (2017): Rapport d'Information fait au nom de la délégation aux entreprises (1) et de la délégation aux collectivités territoriales et à la décentralisation (2) sur la revitalisation des centres-villes et des centres-bourgs du Sénat sur la revitalisation des centresvilles et des centres-bourgs. Paris

Pollitt, C.; Bouckaert, G. (2011): Public management reform: a comparative analysis: new public management, governance, and the neo-Weberian state. Oxford.

Portas, M. (ed.) (2011): The Portas review. An independent review into the future of our high streets. London.

Pumain, D.; Moriconi-Ebrard, F. (1997): City size distributions and metropolisation. In: GeoJournal 43, 307-314. https://doi.org/10.1023/A:1006833025206

Razemon, O. (2017): Comment la France a tué ses villes. Paris.

Roth, H. (2016): Du déclin à la périphérisation: quand les courants constructivistes et critiques revisitent les différenciations spatiales en Allemagne. In: Cybergeo 758. https://doi.org/10.4000/cybergeo.27389
Santamaria, F. (2000): La notion de 'ville moyenne' en France, en Espagne et au Royaume-Uni. In: Annales de Géographie 109, 227-239.

Santamaria, F. (2012): Les villes moyennes françaises et leur rôle en matière d'aménagement du territoire: vers de nouvelles perspectives? In: Norois. Environnement, Aménagement, Société 223, 13-30. https://doi.org/10. 4000/norois.4180

Sassen, S. (1991): The global city: New York, London, Tokyo. Princeton.

Scott, A.J.; Storper, M. (2003): Regions, globalization, development. In: Regional Studies 37, 6-7, 579-593. https://doi.org/10.1080/0034340032000108697a

Tallec, J. (2014): La construction socio-spatiale de l'innovation en ville moyenne face aux objectifs de compétitivité et d'attractivité des politiques d'aménagement: les cas des agglomérations d'Albi (Midi-Pyrénées), Alès (Languedoc-Roussillon), Fougères et Quimper (Bretagne). Toulouse.

Taulelle, F. (2012): Ce que nous avons vu en matière de services publics dans les quatre pays de l'étude: le délaissement du territoire. In: Sciences de la Société 86, 5-13. https://doi.org/10.4000/sds. 1634

Taulelle, F. (2017): Faut-il encore se préoccuper des services publics dans les territoires hors métropoles? In: Courcelle, T.; Fijalkow, Y.; Taulelle, F. (eds.): Services publics et territoires: adaptations, innovations et réactions. Rennes, 21-31.

Vadelorge, L. (2013): Les villes moyennes ont une histoire. In: L'Information Géographique 77, 3, 29-44.

Wolff, M.; Fol, S.; Roth, H.; Cunningham-Sabot, E. (2013): Shrinking Cities, villes en décroissance: une mesure du phénomène en France. In: Cybergeo 661. https://doi.org/ 10.4000/cybergeo. 26136

Wolff, M.; Wiechmann, T. (2018): Urban growth and decline: Europe's shrinking cities in a comparative perspective 1990-2010. In: European Urban and Regional Studies 25, 2, 122-139. https://doi.org/10.1177/ 0969776417694680 